\title{
Pelatihan Akuntansi bagi Komunitas Usaha Ekonomi Kreatif Kayoetangan Heritage Kota Malang: Optimalisasi Media Daring
}

\author{
Zahroh Zainah Abidin, Maria Goretti Wi Endang, Dwiatmanto Dwiatmanto, Raden Rustam \\ Hidayat, Rachma Bhakti Utami \\ Departemen Administrasi Bisnis, Fakultas Ilmu Administrasi, Universitas Brawijaya Malang, \\ Jl. MT. Haryono No.163, Malang, 65145, Indonesia
}

\author{
ARTICLE INFO \\ Received: 2020-12-20 \\ Revised: 2021-02-06 \\ Accepted: 2021-04-02 \\ Keywords: \\ Community service, \\ Kayoetangan heritage \\ creative economy \\ business community, \\ Online media, Simple \\ accounting training
}

\begin{abstract}
Understanding and preparing basic financial reports is essential and necessary for every entrepreneur. This Community Service Activity is essential to do, considering that not many members of the Komunitas Usaha Ekonomi Kreatif Kayoetangan Heritage of Malang City have made financial records for their business. A total of 27 members and administrators of the Komunitas Usaha Ekonomi Kreatif Kayoetangan Heritage participated in this training. The main purpose of this community service activity is to provide simple training on theapreparation of basic accounting financialareports, both for service companies and trading companies. The lecture method is used in this community service. Unfortunately, pandemic conditions hampered the implementation of this training. Researchers then used online or online methods as a training solution amid a pandemic. The training results showed that the participants were enthusiastic about participating in this training, which was shown by the participants being active in conducting discussions. The participants' assessment of the training activities was excellent. For training and community service in the future, assistance should be provided to training participants to implement financial reports for entrepreneurs fully.
\end{abstract}

(C) 2021 Published by University of Merdeka Malang. This is an open access article distributed under the CC BY-SA 4.0 license

(https://creativecommons.org/licenses/by-sa/4.0/)

How to cite: Abidin, Z. Z., Endang, M. G. W., Dwiatmanto, D., Hidayat, R. R., \& Utami, R. B. (2020). Pelatihan Akuntansi bagi Komunitas Usaha Ekonomi Kreatif Kayoetangan Heritage Kota Malang: Optimalisasi Media Daring. Abdimas: Jurnal Pengabdian Masyarakat Universitas Merdeka Malang, 6(2), 230-240. https://doi.org/10.26905/abdimas.v6i2.5161

\section{PENDAHULUAN}

Di era global saat ini, setiap anggota masyarakat senantiasa dihadapkan pada permasalahan dan tantangan yang lebih kompleks. Dalam kondisi seperti ini kita sebagai individu yang memiliki potensi bakat bisnis tidak sekedar dituntut untuk antisipatif, tetapi harus lebih proaktif dalam merancang pengembangan usaha yang benar-benar kompetitif (Nurhidayati \& Fachrunnisa, 2020). Penggalian 
potensi usaha yang optimal diiringi perencanaan yang cermat dengan segala aspeknya menjai poin penting sebagai dasar penentuan strategi pengetahuan usaha bagi pengelola bisnis.

Suatu perencanaan yang dituangkan dan dikaji secara matang sangat penting bagi pengusaha, terutama para pengelola usaha mikro, kecil dan menengah. Perencanaan yang matang akan membantu para pengelola untuk bekerja lebih mudah, menjaga arah, dan menolong para pengelola untuk mencapai keinginan dan tujuan yang diharapkan (Wijaya \& Rifa'i, 2016). Suatu perencanaan akan mudah dicapai apabila memperhatikan beberapa hal berikut ini: (1) Suatu perencanaan harus realistis, jangan membuat rencana terlalu muluk, sedangkan kemampuan tidak mendukung; (2) Dengan perencanaan usaha, akan diketahui masalah-masalah yang mungkin timbul. Oleh karena itu, perlu saran-saran dari orang yang lebih berkompeten dan dapat membantu memecahkan masalah tersebut; (3) Memperhatikan perubahan-perubahan yang mungkin terjadi atau setidaknya mengenalinya, sehingga dapat dipakai sebagai alat untuk membuat strategi usaha yang tepat; (4) Berusaha untuk tidak lepas dari tujuan yang diinginkan semula, hal ini memudahkan pengawasan terhadap usaha yang dijalankan.

Dengan perencanaan usaha yang matang, kemungkinan kerugian akan dapat dihindari baik yang bersifat operasional maupun organisasional (Rusdiana, 2014). Kajian dan penelaahan dari berbagai aspek akan dapat memberikan gambaran yang mencerminkan layak atu tidaknya suatu usaha itu dijalankan. Hal ini sesuai dengan fungsi manajemen yang meliputi pengorganisasian, perencanaan, pengarahan, dan evaluasi. Kegiatan ini dilakukan untuk menentukan tujuan dan mencapai hasil yang telah ditetapkan melalui pemanfaatan sumber daya manusia dan sumber daya lainnya (Abdullah, 2017). Yang perlu dicermati dalam kaitannya dengan fungsi manajemen tadi adalah aspek keuangan. Dana dalam organisasi perusahaan, bagaikan arah dalam kehidupan manusia, apabila kekurangan, maka akan berpengaruh sehingga setiap kegiatan operasional semakin lesu. Dampak dari situasi yang demikian ini tentunya akan berpengaruh terhadap tujuan yang akan diraih, oleh karenanya dibutuhkan pengelolaan keuangan yang baik dengan diikuti oleh pencatatan sesuai kaidah akuntansi yang berlak saat ini sehingga akan dihasilkan laporan keuangan yang baik (Yuesti et al., 2020).

Menurut (Riswan \& Kesuma, 2014) laporan keuangan adalah hasil akhir dari suatu produk pencatatan yang berupa ringkasan transaksi keuangan selama tahun buku perusahaan. Melalui laporan keuangan ini akan dapat diketahui bagaimana kinerja yang telah dilakukan perusahaan tersebut. Ironisnya, justru pencatatan akuntansi inilah yang seringkali tidak dilakukan dengan baik utamanya untuk usaha pemula dan masih dalam skala kecil sehingga seringkali usaha tidak dapat berkembang maksimal, banyak fasilitas yang diberikan oleh pemerintah untuk menumbuhkan usaha mikro, kecil, dan menengah utamanya pada aspek keuangan (Yuningsih \& Silaningsih, 2020). Namun, pada kenyataanya tidak semua UMKM dapat mendayagunakan fasilitas dan potensi tersebut. Padahal pemerintah Kota Malang saat sekarang benar-benar ingin mengembangkan kawasan Kayoetangan sebagai salah satu ikon wisata Kota Malang. Kampoeng Kayoetangan diharapkan menjadi sentra usaha kreatif didalamnya. Untuk itu pelatihan akuntansi sangat diperlukan.

Saat ini, tim pengabdian berupaya untuk memberikan bantuan melalui pengadaan pelatihan akuntansi kepada UMKM di Kampoeng Kayutangan. Namun, pada praktiknya, terdapat beberapa kesulitan serta hambatan yang ditemui tim pengabdian. Diantaranya seperti: (1) Kondisi pandemi 
ABDIMAS: Jurnal Pengabdian Masyarakat Universitas Merdeka Malang

Volume 6, No. 2, May 2021: 230-240

COVID-19 yang tidak diperkirakan sebelumnya, sehingga pendekatan dan pelatihan rencananya akan dilakukan secara daring; (2) SDM yang akan diberi pelatihan terdiri dari berbagai tingkatan pendidikan yang heterogen, sehingga untuk mendapatkan pemahaman yang mudah diterima, perlu ketelatenan dan pelatihan; (3) Tidak semua peserta menguasai teknologi informasi.

Namun demikian, mengingat pentingnya permasalahan tentang perlunya pemahaman akuntansi ini, maka tim pengabdian merasa perlu adanya pelatihan tentang akuntansi bagi komunitas Kayoetangan Heritage Malang agar senantiasa dapat meningkatkan bakat bisnisnya dan akhirnya dapat mendukung pembangunan ekonomi masyarakat. Berdasarkan hasil wawancara dengan ketua komunitas Kampoeng Kayoetangan, terdapat informasi bahwa komunitas ini beranggotakan kurang lebih 30 warga masyarakat di 3 RW yang memiliki bangunan atau rumah yang berasirtektur kolonial Belanda yang sejak saat sebelum pandemi sangat banyak dikunjungi oleh wisatawan dan untuk memenuhi kebutuhan wisatawan, maka didirikan berbagai rumah makan dengan nuansa ikonik sesuai dengan tema heritage dimana merekajuga bagian dari komunitas. Permasalahannya, karena anggota komunitas terdiri dari beragam latar belakang pendidikan maka mereka belum melakukan pengelolaan keuangan secara benar. Terlebih di kondisi pandemi COVID-19 ini, basis Kampoeng Kajoetangan Heritage pada sektor pariwisata sangat terdampak. Pandemi COVID-9 telah mengubah kondisi "kenormalan" di semua sektor kehidupan termasuk pada kegiatan sektor wisata. (Wikantiyoso et al., 2020). Tim pengabdian berharap meskipun sedang dalam kondisi pandemi, Komunitas Ekonomi Kreatif di Kajoetangan ini dapat menemukan solusi serta tetap melakukan peningkatan (upgrade skill) termasuk dalam hal pemahaman terkait laporan keuangan.

Adanya pelatihan keuangan ini maka tim pengabdian berharap dapat meningkatkan kualitas UMKM Kampoeng Kayutangan, meningkatkan kompetensi yang dimiliki UMKM serta meningkatkan komersialisasi dan menerapakan ekonomi kreatifyang lebih berkualitas sehingga selaras dengan roadmap penelitian dari Badan Penelitian dan Pengabdian Masyarakat (BPPM) Fakultas IImu Administrasi (FIA) Universitas Brawijaya tahun 2016-2020 yakni Pencapaian Ekonomi Kreatif dan Bisnis Lokal. Adapun luaran yang diharapkan dari kegiatan pengabdian ini tentu saja adalah peningkatan kualitas UMKM Kampoeng Kayoetangan khususnya di bidang akuntansi keuangan dengan diberikannya pelatihan secara sederhana tentang bagaimana penyusunan laporan keuangan akuntansi dasar, baik pada perusahaan jasa maupun perusahaan dagang.

\section{METODE}

\section{Metode kegiatan}

Agar tujuan yang hendak dicapai dari Pengabdian Kepada Masyarakat ini efektif, maka metode yang dipakai adalah sebagai berikut: (1) Ceramah, yaitu memberikan penjelasan tentang proses pencatatan transaksi kegiatan operasional, sehingga para peserta mampu menyusun laporan keuangan, minimal laporan rugi-laba dan neraca untuk kepentingan perusahaan. Untuk pelaksanaan metode ini, digunakan alat bantu untuk penyampaian, yaitu penyajian materi memakai Power Point; (2) Diskusi, agar materi yang disampaikan tersebut dapat diketahui apakah sudah dipahami oleh para peserta, maka disamping ceramah juga diberi kesempatan untuk diskusi. Tanya jawab tentang proses pencatatan transaksi kegiatan operasional. 


\section{Kerangka pemecahan masalah}

Kerangka pemecahan masalah adalah serangkaian prosedur dan langkah yang dilalui dalam suatu penelitian atau pengabdian yang bertujuan untuk mendapatkan tahapan yang terstruktur, sehingga penelitian dan pengabdian dapat dilakukan dengan efektif dan efisien. Pada pengabdian masyarakat ini, permasalahan yang ada adalah masih rendahnya pengetahuan akan pencatatan laporan keuangan pada UMKM di Kampoeng Heritage Kota Malang. Diharapkan dengan adanya pelatihan akuntansi sederhana ini akan meningkatkan kualitas UMKM Kayoetangan Heritage khususnya pada bidang Akuntansi Keuangan dan Pencatatan Laporan Keuangan. Namun, terdapat hambatan pelaksanaan pelatihan ini yakni adanya Pandemi COVID-19.

Solusi yang tim pengabdian berikan adalah pelatihan menggunakan media online/daring. Seluruh pengurus Pokdarwis Kayoetangan menyambut antusias pelatihan berbasis online ini karena baru pertama kali dilaksanakan. Selain tentunya diharapkan tujuan utama dari pelatihan ini yakni peningkatan pemahaman UMKM akan pentingnya pencatatan laporan keuangan, seluruh pelaku bisnis di Kayoetangan Heritage memperoleh pengalalaman baru dengan adanya pelatihan akuntansi berbasis online ini. Gambar 1 menunjukkan kerangka pemecahan masalah pada pelatihan akuntansi sederhana ini.

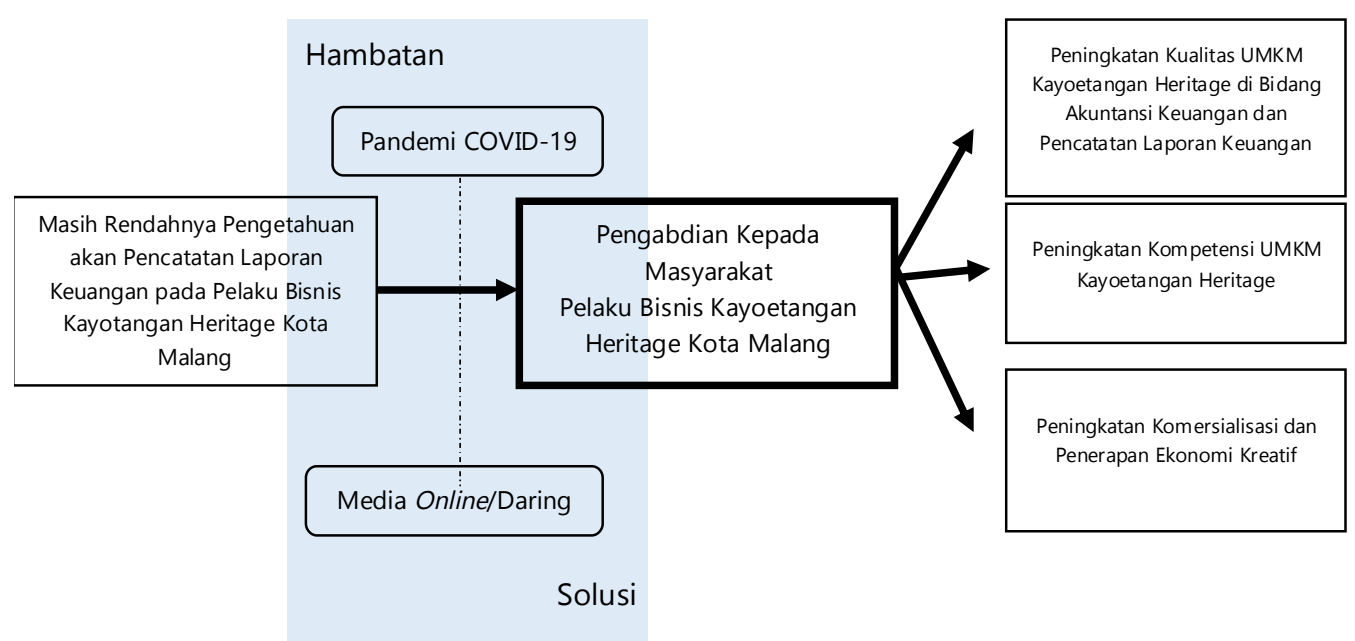

Gambar 1. Kerangka pemecahan masalah pelatihan akuntansi dasar

\section{HASIL DAN PEMBAHASAN}

Pada awalnya, pengabdian masyarakat berupa "Pelatihan Akuntansi bagi Komunitas Usaha Ekonomi Kreatif Kayoetangan Heritage Kota Malang" ini akan diadakan secara offline. Namun, dikarenakan adanya pandemi COVID-19, maka pelaksanaan dilakukan dengan metode daring memanfaatkan media komunikasi dan pembelajaran Zoom. Lokasi pengabdian adalah Kampoeng Heritage Kajoetangan, berada di Jalan Jenderal Basuki Rachmat Gang VI, Kauman, Klojen, Kota Malang. Berjarak antara 4,2 km hingga 5,2 km dengan Universitas Brawijaya. Memerlukan waktu 10-14 menit mencapai lokasi pengabdian dari Universitas Brawijaya jika mengendarai kendaraan roda empat. 
ABDIMAS: Jurnal Pengabdian Masyarakat Universitas Merdeka Malang Volume 6, No. 2, May 2021: 230-240

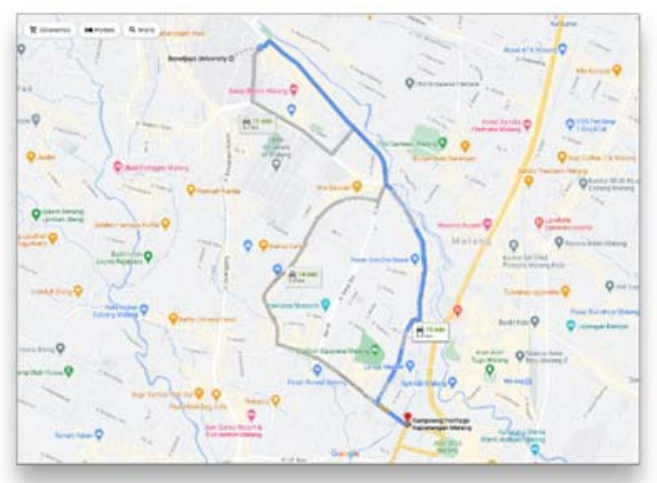

Gambar 2. Peta lokasi dan jarak lokasi pengabdian dengan Universitas Brawijaya Kota Malang

Pelaksanaan pengabdian masyarakat berupa "Pelatihan Akuntansi bagi Komunitas Usaha Ekonomi Kreatif Kayoetangan Heritage Kota Malang" ini telah selesai dilaksanakan, dengan rincian pelaksanaan sebagai berikut.

\section{Profil peserta pelatihan}

Peserta "Pelatihan Akuntansi bagi Komunitas Usaha Ekonomi Kreatif Kayoetangan Heritage Kota Malang" ini adalah 27 UMKM di Kampoeng Heritage Kayoetangan Kota Malang. Berbagai usaha yang dijalankan peserta seperti rumah makan, perdagangan makanan ringan, dan salon. Diantara 27 peserta pelatihan tersebut, terdapat 9 Pengurus dan Manajemen Pokdarwis Kayoetangan. Pelatihan ini selain memberi ilmu terkait pencatatan laporan keuangan, pada sesi terakhir atau pertemuan ke-4 diadakan sharing session dan tanya jawab dimana para pengusaha UMKM serta manajemen pengurus Pokdarwis Kayoetangan mengemukakan kendala yang dihadapi, terlebih saat melewati masa pandemi COVID-19 ini.

Tabel 1. Profil peserta pelatihan

\begin{tabular}{|c|c|c|}
\hline Kriteria & Jumlah & Presentase (\%) \\
\hline \multicolumn{3}{|l|}{ Jenis Kelamin } \\
\hline Pria & 6 & 22 \\
\hline Wanita & 21 & 78 \\
\hline \multicolumn{3}{|l|}{ Umur } \\
\hline 17-27 Tahun & 0 & 0 \\
\hline 28-38 Tahun & 5 & 19 \\
\hline 39-49 Tahun & 13 & 48 \\
\hline 50-60 Tahun & 7 & 26 \\
\hline > 60 Tahun & 2 & 7 \\
\hline \multicolumn{3}{|l|}{ Pendidikan } \\
\hline SD & 0 & 0 \\
\hline SMP & 3 & 11 \\
\hline SMA & 14 & 52 \\
\hline S1 & 10 & 37 \\
\hline$\geq S 2$ & 0 & 0 \\
\hline
\end{tabular}


Pelatihan Akuntansi bagi Komunitas Usaha Ekonomi Kreatif Kayoetangan Heritage Kota Malang: Optimalisasi Media Daring Zahroh Zainah Abidin, Maria Goretti Wi Endang, Dwiatmanto Dwiatmanto, Raden Rustam Hidayat, Rachma Bhakti Utami

\section{Pelaksanaan acara}

Acara dilakukan bertahap dengan 4 pertemuan. Pertemuan I dilaksanakan pada Sabtu, 29 Agustus 2020 dengan materi Pelatihan Akuntansi Dasar. Pemateri pertemuan I ini adalah Dr. Dra. Zahroh Z. A., M. Si dengan moderator Dr. Dra. Maria Goretti Wi Endang NP. M.Si. Waktu pelaksanaan pukul 13.00-14.30 WIB. Ringkasan materi pertemuan I adalah, akuntansi merupakan proses pencatatan, penggolongan, peringkasan, dan penganalisisan data keuangan suatu organisasi (Ritonga, 2017). Sedangkan dari sudut pemakai, akuntansi adalah suatu disiplin yang menyediakan informasi yang diperlukan untuk melaksanakan kegiatan secara efisien dan mengevaluasi kegiatan-kegiatan suatu organisasi (Jusup, 2011).
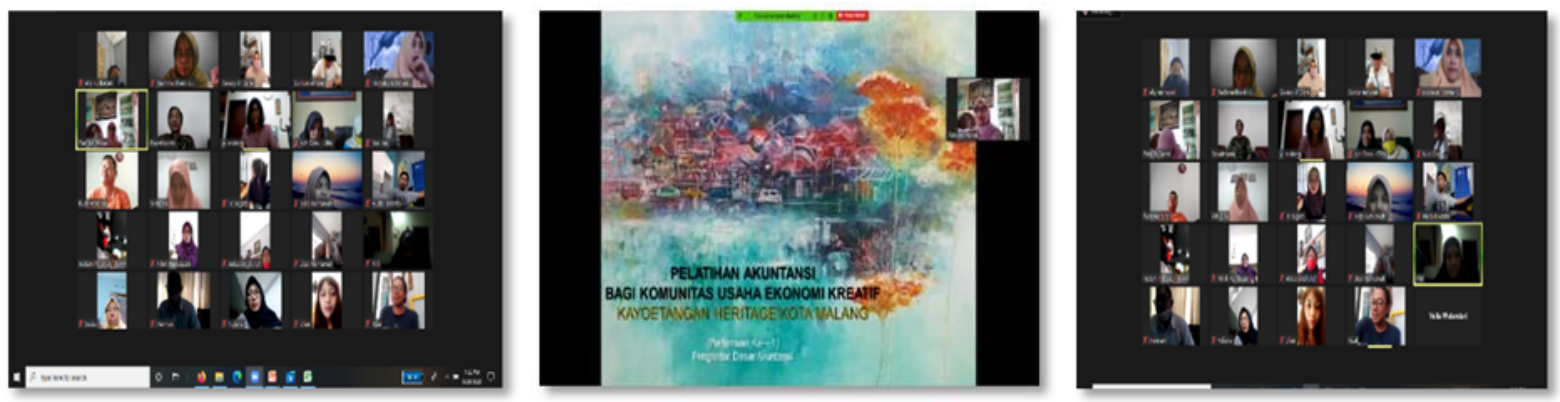

Gambar 3. Pertemuan I pelatihan akuntansi Komunitas Ekonomi Kreatif Kayoetangan Heritage Kota Malang

Gambar 3 menunjukkan pelaksanaan pertemuan I (pertama) pelatihan akuntansi pada Komunitas Ekonomi Kreatif Kajoetangan Heritage Kota Malang. Pelatihan yang dilaksanakan pada hari Sabtu, 29 Agustus 2020 tersebut membahas mengenai dasar-dasar akuntansi. Pelatihan pertama tersebut menekankan pada pentingnya pencatatan uang keluar dan uang masuk bagi seluruh pengusaha, baik mereka yang bergerak pada usaha dagang maupun usaha jasa.

Pertemuan II dilaksanakan pada Sabtu, 5 September 2020 dengan materi Pembukuan Akuntansi Perusahaan Jasa. Pemateri pertemuan II adalah Dr. Drs. Dwiatmanto., M. Si dengan dimoderatori oleh Rachma Bhakti Utami, SE., MAB. Waktu pelaksanaan pertemuan II pukul 13.00-14.30 WIB. Ringkasan materi pertemuan ini terkait akuntansi perusahaan jasa yang dituangkan dalam bagian II dari modul ini adalah "Persamaan Dasar Akuntansi". Urutan penyajian materi diatur sebagai berikut: (1) Pengertian dan rumusannya; (2) Transaksi keuangan dan persamaan akuntansi; (3) Laporan keuangan (financial statement) berupa neraca, laporan laba dan rugi, serta laporan perubahan modal. Uraian materi tersebut dilengkapi dengan contoh kasus yang mungkin terjadi di perusahaan jasa, baik yang berskala kecil hingga yang berskala besar. 
ABDIMAS: Jurnal Pengabdian Masyarakat Universitas Merdeka Malang

Volume 6, No. 2, May 2021: 230-240
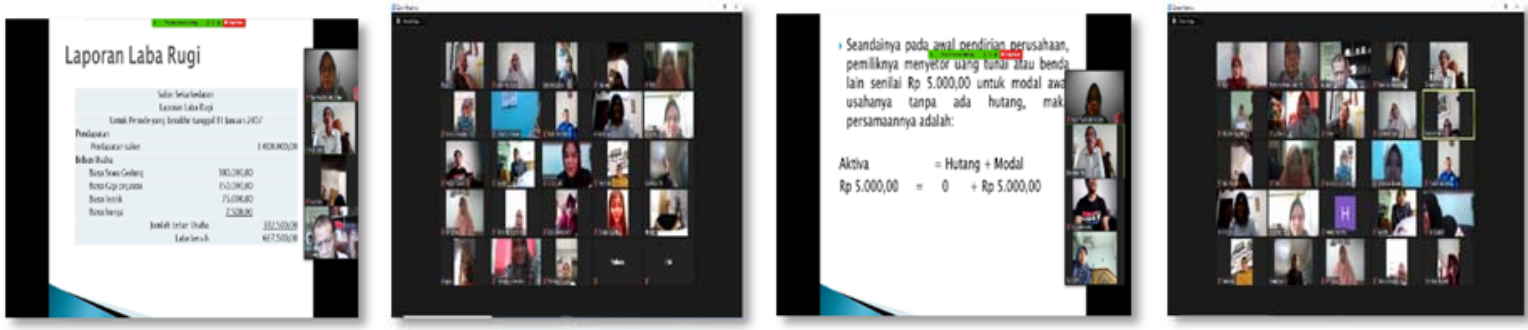

Gambar 4. Pertemuan II pelatihan akuntansi Komunitas Ekonomi Kreatif Kayoetangan Heritage Kota Malang

Gambar 4 menunjukkan pelaksanaan pertemuan II (kedua) pelatihan akuntansi pada Komunitas Ekonomi Kreatif Kajoetangan Heritage Kota Malang. Pelatihan yang dilaksanakan pada hari Sabtu, 5 September 2020 tersebut membahas mengenai dasar-dasar akuntansi. Pelatihan kedua tersebut fokus pada pencatatan laporan keuangan khususnya pada perusahaan jasa. Dicontohkan pada pelatihan ini usaha jasa yakni salon. Pemilihan usaha ini menyesuaikan kondisi di lokasi pengabdian yang terdapat beberapa pengusaha salon.

Pertemuan III dilaksanakan pada Sabtu, 12 September 2020 dengan materi Pelatihan Akuntansi Dasar. Pemateri pada pertemuan III ini adalah Dr. Dra. Zahroh Z. A., M. Si dan dimoderatori oleh Dr. Dra. Maria Goretti Wi Endang NP. M.Si. Waktu pelaksanaan pada pukul 13.00-14.30 WIB. Ringkasan materi mengenai Akuntansi Perusahaan Dagang. Pada materi ini membahas komponen harga jual yang menguntungkan, terdiri dari: (1) Harga pokok barang yang dijual; (2) Biaya operasi perusahaan sepert, biaya atau pegawai, biaya sewa, beban asuransi dsb; (3) Laba bersih yang ditargetkan perusahaan. Komponen Harga Pokok Penjualan, terdiri dari: (1) Persediaan Awal; (2) Harga pokok pembelian; (3) Harga pokok barang yang tersedia untuk dijual, dan persediaan akhir. Rekening yang ada dalam perusahaan dagang, terdiri dari: Penjualan, Retur dan potongan penjualan, Potongan tunai penjualan, Pembelian, retur dan potongan pembelian, Potongan tunai pembelian, biaya angkut pembelian, hingga persediaan barang dagangan.
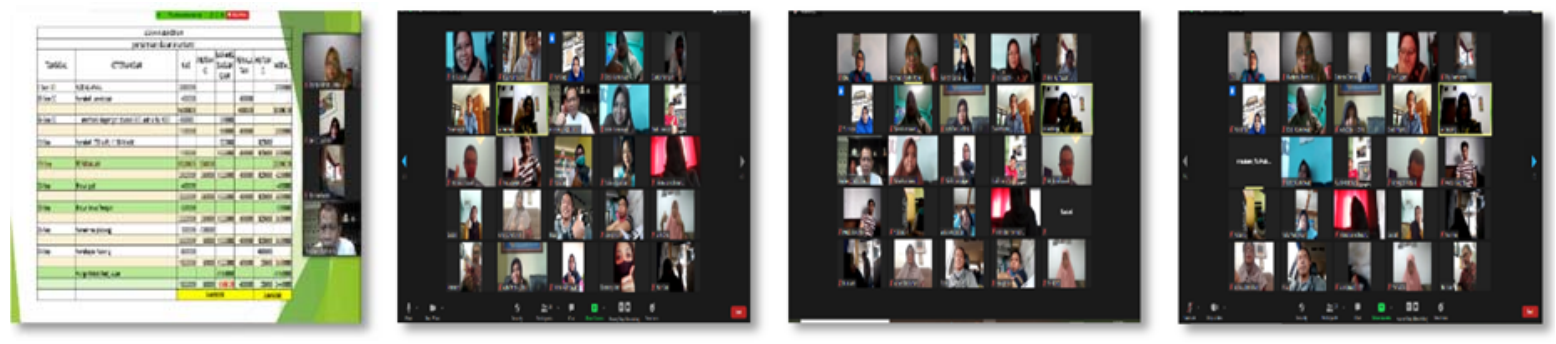

Gambar 5. Pertemuan III pelatihan akuntansi Komunitas Ekonomi Kreatif Kayoetangan Heritage Kota Malang

Gambar 5 menunjukkan pelaksanaan pertemuan III (ketiga) pelatihan akuntansi pada Komunitas Ekonomi Kreatif Kajoetangan Heritage Kota Malang. Pelatihan yang dilaksanakan pada hari Sabtu, 12 
Pelatihan Akuntansi bagi Komunitas Usaha Ekonomi Kreatif Kayoetangan Heritage Kota Malang: Optimalisasi Media Daring Zahroh Zainah Abidin, Maria Goretti Wi Endang, Dwiatmanto Dwiatmanto, Raden Rustam Hidayat, Rachma Bhakti Utami

September 2020 tersebut membahas mengenai dasar-dasar akuntansi. Pelatihan kedua tersebut fokus pada pencatatan laporan keuangan khususnya pada perusahaan dagang. Pembedaan jenis usaha pada pengadian ini diharapkan agar para peserta pelatihan dapat membedakan proses pencatatan laporan keuangan pada perusahaan dagang dan perusahaan jasa. Pemilihan pelatihan laporan keuangan dasar pada perusahaan dagang ini dilakukan karena terdapat banyak pedagang di lokasi pengabdian.

Pertemuan IV dilaksanakan pada Sabtu, 19 September 2020 dengan materi Diskusi dan Tanya Jawab. Pemateri pada pertemuan ini adalah seluruh anggota tim pengabdian dengan dimoderatori oleh Rachma Bhakti Utami, S.E., M. AB
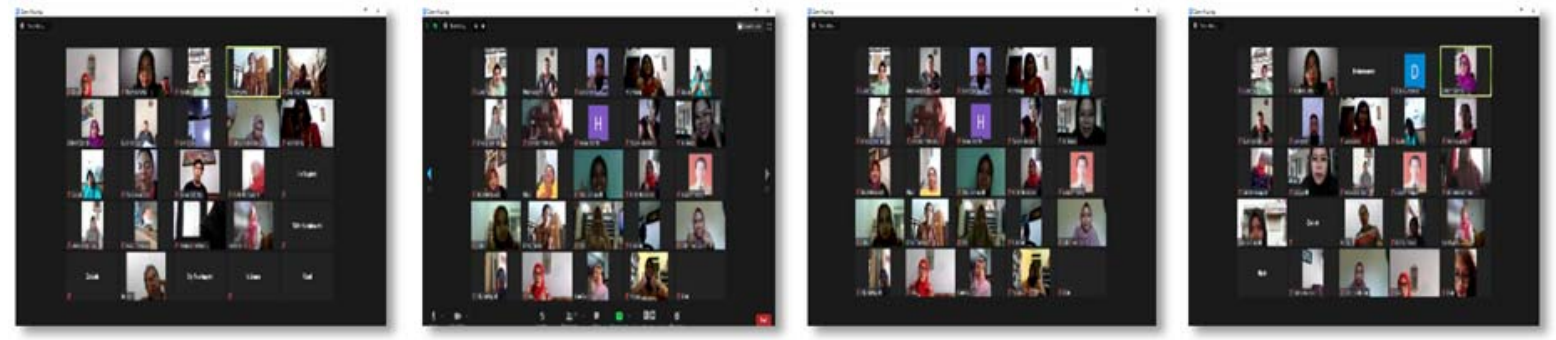

Gambar 6. Pertemuan IV pelatihan akuntansi Komunitas Ekonomi Kreatif Kayoetangan Heritage Kota Malang

Gambar 6 menunjukkan pelaksanaan pertemuan IV atau yang terakhir dari serangkaian pelatihan akuntansi pada Komunitas Ekonomi Kreatif Kajoetangan Heritage Kota Malang. Pelatihan yang dilaksanakan pada hari Sabtu, 19 September 2020 tersebut lebih pada adanya diskusi serta tanya jawab antara peserta pelatihan dan pemateri. Mayoritas peserta pelatihan menyampaikan keluhan tersendatnya usaha karena adanya pandemi COVID-19 ini. Pada acara diskusi ini disampaikan pula beberapa tips dari pemateri terkait solusi usaha ditengah pandemi, diantaranya harus dilakukan inovasi penjualan melalui sarana media online. Selain diskusi dan tanya jawab, para peserta cukup mengapresiasi adanya pelatihan akuntansi ini dan mengharapkan adanya lanjutan proses pendampingan dari tim pengabdian kepada komunitas usaha kreatif Kampoeng Kajoetangan Heritage. Adapun publikasi berupa video pelaksanaan acara, dapat dilihat pada YouTube (Uthe, 2020).

\section{Capaian evaluasi dan keberhasilan kegiatan}

Pada bagian awal dan akhir pelatihan ini juga telah dilakukan pre-test dan post-test atas pemahaman awal para peserta pelatihan dan setelah pelatihan. Pertanyaan yang ada terdiri dari 10 (sepuluh) pertanyaan tentang konsep dan praktik dasar akuntansi keuangan dan pelaporan keuangan. Hasil jawaban peserta pelatihan ditunjukkan pada tabel di bawah ini. Tabel 2 mengindikasikan bahwa terjadi peningkatan pengetahuan dan pemahaman konsep dan praktik akuntansi keuangan peserta pelatihan, sebelum dan sesudah pelatihan. Hal ini dapat diartikan bahwa pelatihan ini telah mendapatkan tujuannya. Evaluasi yang dilaksanakan melalui kegiatan pre test dan post test. Adapun hasil dari kegiatan ini dapat ditunjukkan pada tabel 2. 
ABDIMAS: Jurnal Pengabdian Masyarakat Universitas Merdeka Malang

Volume 6, No. 2, May 2021: 230-240

Tabel 2. Hasil pre-test dan post-test pelatihan akuntansi

\begin{tabular}{ccccc}
\hline \multirow{2}{*}{ Soal No. } & \multicolumn{2}{c}{ Pre-Test } & \multicolumn{2}{c}{ Post-Test } \\
\cline { 2 - 5 } & Jawaban Benar & Jawaban Salah & Jawaban Benar & Jawaban Salah \\
\hline 1 & 15 & 12 & 26 & 1 \\
2 & 6 & 21 & 20 & 7 \\
3 & 6 & 21 & 19 & 8 \\
4 & 19 & 8 & 20 & 7 \\
5 & 11 & 16 & 26 & 1 \\
6 & 13 & 14 & 21 & 6 \\
7 & 11 & 16 & 26 & 1 \\
8 & 9 & 18 & 20 & 7 \\
9 & 19 & 8 & 26 & 1 \\
10 & 19 & 8 & 26 & 1 \\
\hline
\end{tabular}

Kegiatan pelatihan akuntansi dasar yang telah dilaksanakan ini menunjukkan rasa antusias yang sangat tinggi dari peserta yang merupakan para pengusahan UMKM dan pengurus Pokdarwis Kampoeng Heritage Kayoetangan Kota Malang. Antusiasme tersebut ditunjukkan dengan aktifnya diskusi dan banyaknya pertanyaan yang diajukan seputar penyusunan laporan arus kas serta laporan keuangan pendukungnya. Narasumber atau pemateri berusaha untuk menjawab pertanyaan dari peserta tersebut dan memberikan penjelasan yang mendalam mengenai topik yang ditanyakan. Tentu saja pelaksana atau narasumber berharap agar untuk kedepannya kendala yang dihadapi dalam penyusunan laporan keuangan dapat diatasi. Selain itu diharapkan materi yang diberikan dalam pelatihan tersebut dapat langsung dipraktikkan dalam kondisi nyata pada usaha yang dijalankan warga Kayoetangan. Saat membahas laporan keuangan baik pada perusahaan jasa maupun perusahaan dagang yang telah disusun oleh pemateri, nampak bahwa peserta pelatihan belum bisa membaca laporan keuangan tersebut dengan baik.

Menurut pengamatan pelaksana, bahwa selama pelaksanaan kegiatan pelatihan akuntansi tersebut nampak bahwa pengusaha/pelaku usaha UMKM di Kampoeng Heritage Kayoetangan Kota Malang sangat awam dalam menyusun laporan keuangan. Hal ini membuktikan bahwa selama ini masih kurangnya kesadaran para pengusaha/pelaku usaha UMKM di Kampoeng Heritage Kayoetangan Kota Malang untuk menyusun dan menganalisis laporan keuangan. Padahal hal tersebut sangat penting mengingat setiap pengusaha wajib untuk mengetahui kondisi kas usaha baik dari aktivitas operasional investasi, maupun pendanaan, karena sebagian besar aset usaha berasal dari kas yang ada. Bahkan sebagian besar para pengelola pengusaha/ pelau usaha UMKM di Kampoeng Heritage Kayoetangan Kota Malang tersebut tidak begitu mengetahui mengenai pentingnya penyusunan laporan arus kas maupun laporan keuangan pendukungnya. Kedepannya, peserta pelatihan berharap kegiatan pelatihan seperti ini dapat terus dilaksanakan lagi untuk tahuntahun kedepannya secara berkesinambungan. 


\section{SIMPULAN DAN SARAN}

Selama pelaksanaan kegiatan pelatihan "Pelatihan Akuntansi bagi Komunitas Usaha Ekonomi Kreatif Kayoetangan Heritage Kota Malang" tersebut tidak ada hambatan. Kegiatan dapat dilaksanakan dengan lancar meskipun dilaksanakan secara daring menggunakan media Zoom. Semua peserta yang diundang hadir dalam kegiatan pelatihan. Dikarenakan masih banyak peserta pelatihan pengusaha/pelaku usaha UMKM di Kampoeng Heritage Kayoetangan Kota Malang yang belum melakukan penyusunan laporan keuangan untuk usahanya, ada sedikit kesulitan pada saat menjelaskan pospos yang ada dalam laporan keuangan yang disampaikan dalam materi pelatihan. Namun, peserta berusaha untuk memahami dengan mendalam mengenai laporan arus kas. Sehingga, nantinya dapat segera dilakukan koordinasi dengan bagian-bagian yang menangani laporan keuangan di masing-masing unit usaha.

Sebagian besar pengusaha/pelaku usaha UMKM di Kampoeng Heritage Kayoetangan Kota Malang masih lemah dalam hal penempatan sumber daya manusia yang memang benar-benar handal dalam menangani pembukuan (laporan keuangan), hal ini cukup dimaklumi karena skala usaha di Kampoeng heritage Kota Malang masih kecih. Hal tersebut mengakibatkan laporan keuangan yang disusun belum sesuai dengan kriteria yang baik. Hal yang diperlukan adalah peningkatan kualitas oleh owner dari masing-masing usaha melalui pemahaman yang lebih terkait pentingnya laporan keuangan dan cara penyusunannya. Selain itu, bagi penelitian maupun pengabdian masyarakat selanjutnya, dapat dilakukan pendampingan kepada peserta pelatihan. Proses pendampingan secara kontinyu akan mengontrol luaran hasil pengabdian. Seperti misal saat dilakukan pelatihan penyusunan laporan keuangan, proses pendampingan dilakukan agar penyusunan laporan keuangan oleh peserta telah dilakukan dan terus dilakukan tiap bulannya.

\section{DAFTAR PUSTAKA}

Abdullah, H. (2017). Peranan manajemen sumberdaya manusia dalam organisasi. Jurnal Warta, (51), $1-11$.

Jusup, A. (2011). Dasar-Dasar Akuntansi. Yogyakarta: STIE YKPN.

Nurhidayati, N., \& Fachrunnisa, O. (2020). Manajemen Bisnis di Era Pandemi COVID-19 \& New Normal. Indonesia: Unissula Press.

Riswan, R., \& Kesuma, Y. F. (2014). Analisis laporan keuangan sebagai dasar dalam penilaian kinerja keuangan PT. Budi Satria Wahana Motor. Jurnal Akuntansi \& Keuangan, 5(1), 93-121. http://dx.doi.org/10.36448/jak.v5i1.449

Ritonga, P. (2017). Analisis akuntansi zakat berdasarkan PSAK No. 109 pada Badan Amil Zakat Nasional (BAZNAS) Sumatera Utara. KITABAH: Jurnal Akuntansi dan Keuangan Syariah, 1(1).

Rusdiana, H. A. (2014). Manajemen Operasi. Bandung: CV Pustaka Setia.

Uthe, R. (2020, November 11). Pengabdian Masyarakat - Pelatihan Akuntansi Kampoeng Heritage Kota Malang [Video]. YouTube. Retrieved from: https://www.youtube.com/watch?v=goJsGHc0RJw 
ABDIMAS: Jurnal Pengabdian Masyarakat Universitas Merdeka Malang

Volume 6, No. 2, May 2021: 230-240

Wijaya, C., \& Rifa'i, M. (2016). Dasar Dasar Manajemen: Mengoptimalkan Pengelolaan Organisasi Secara Efektif dan Efesien. Perdana Publishing. Retrieved from: http://repository.uinsu.ac.id/2836/1/ Dasar-Dasar Manajemen.pdf

Wikantiyoso, R., Cahyaningsih, D. S., Sulaksono, A. G., \& Widayati, S. (2020). Protokol new normal order pasca pandemi COVID-19 dalam pengembangan Kampoeng Boenga Grangsil Berbasis Masyarakat. Abdimas: Jurnal Pengabdian Masyarakat Universitas Merdeka Malang, 5(3), 181192. https://doi.org/10.26905/abdimas.v5i3.4803

Yuesti, A., Dewi, N. L. P. S., \& Pramesti, I. G. A. A. (2020). Akuntansi Sektor Publik (Anggaran Sektor Publik). Bali: CV Noah Aletheia.

Yuningsih, E., \& Silaningsih, E. (2020). Manajemen Bisnis \& Inovasi. Bandung: Widina Bhakti Persada. 